\title{
PRESCRIÇÃO EM MATÉRIA DISCIPLINAR
}

\author{
Ronaldo David Viana Barbosa ${ }^{1}$ \\ Reinaldo Denis Viana Barbosa ${ }^{2}$
}

\section{RESUMO:}

O presente artigo trata da prescrição no âmbito do Processo Administrativo Disciplinar. Para tanto, apresenta-se o tratamento dado à matéria pela Lei 8.112/90, destacando-se a problemática em torno do marco inicial para a contagem do prazo prescricional e da referência à utilização dos prazos prescricionais definidos pela lei penal. O problema da pesquisa consiste em identificar se a interpretação da CGU no sentido de que a contagem do prazo prescricional deve iniciar da ciência da autoridade competente para instauração do PAD conforma-se ao Estado de Direito. Utilizando-se método hermenêutico, verifica-se a hipótese inicialmente levantada que dá resposta negativa ao problema.

Palavras-chave: Lei 8.112/90. Processo Disciplinar. Pretensão Punitiva do Estado. Prescrição. Segurança Jurídica.

\section{PRESCRIPTION IN DISCIPLINARY MATTER}

\begin{abstract}
:
This article deals with the prescription in the scope of the Disciplinary Administrative Procedure. For this purpose, the treatment given to the subject by the Law 8.112 / 90 is presented, highlighting the problematic around the initial framework for counting the prescriptive period and referring to the use of the prescriptive periods defined by the criminal law. The research problem is identify if the interpretation of the CGU, in the sense that the counting of the prescriptive period should begin from the science of the competent authority to establish the PAD, conforms to the rule of law. Using an hermeneutical method, it is verified the hypothesis initially raised, that gives a negative answer to the problem.
\end{abstract}

Keywords: Law 8.112 / 90. Disciplinary Procedure. Punitive Pretension of the State. Prescription. Legal Security.

\section{INTRODUÇÃO}

O Processo Administrativo Disciplinar (PAD) é a ferramenta pela qual o Estado, em decorrência do poder hierárquico e disciplinar, propõe-se a corrigir atos de seus servidores.

\footnotetext{
1 Corregedor-geral da Corregedoria da Universidade Federal de Santa Catarina. Graduado em Direito (CESUSC). Especialista em Direito Processual Civil (UFSC) e em Direito Previdenciário (CESUSC). Graduando em Filosofia (UFSC).

${ }^{2}$ Mestrando do PPGD/UFSC. Especialista em Direito Penal e Processual Penal pela Univali. Graduado em Direito pelo CESUSC. Pesquisador do Núcleo de Estudos Criminais da UFPR e do GETEC/UFSC. Advogado.
} 
Considerando não ser desejável que o servidor conviva eternamente com a expectativa de instauração e/ou continuidade do PAD, a Lei 8.112/90 estabelece prazos máximos para o desfecho da apuração. A essa deadline dá-se o nome de prescrição. Embora os prazos sejam claros (pelo menos até fazer referência aos prazos da prescrição em matéria penal), ainda há considerável espaço para reflexões no que se refere ao marco inicial para a contagem do prazo prescricional, uma vez que o legislador limitou-se a definir como início da contagem "a data em que o fato se tornou conhecido", sem especificar por quem.

Uma vez existente esta lacuna, o Órgão Central do Sistema de Correição do Poder Executivo Federal, a Controladoria Geral da União (CGU), tem manifestado entendimento no sentido de que o marco inicial é a ciência da autoridade competente para a instauração do processo disciplinar (CGU, 2017). A partir disso formulou-se o seguinte problema de pesquisa: a interpretação da CGU no sentido de que o marco inicial da contagem do prazo prescricional no Processo Administrativo Disciplinar é a ciência pela autoridade competente para instauração está de acordo com o que preceitua o Estado de Direito? Para responder adequadamente à pergunta formulada foi necessário estabelecer os seguintes objetivos: compreender o tratamento legal e doutrinário da prescrição no âmbito do processo disciplinar; apresentar as penalidades previstas na Lei 8.112/90 e os respectivos prazos prescricionais; e identificar as bases da prescrição em matéria penal.

A partir da compreensão da matéria pelo atingimento dos objetivo estipulados, sugere-se leitura extensiva do $\$ 3^{\circ}$ do artigo 142 da Lei 8.112/90, no sentido de que na verificação dos prazos prescricionais de infrações disciplinares também definidas como crime sejam consideradas as majorantes e minorantes obrigatórias, bem como a redução do prazo à metade motivada pela idade do agente no momento da prática do ato (se menor de 21 anos) ou no momento da sentença (se maior de 70 anos).

Finalmente, como resposta à pergunta formulada, sustenta-se que a interpretação dada pela CGU não é a mais adequada se considerados os pressupostos do Estado de Direito, tais como segurança jurídica, previsibilidade e estabilidade das relações, motivo pelo qual a hipótese que nega a pergunta é confirmada, sugerindo seja a interpretação no sentido de que o marco inicial da contagem do prazo prescricional deva ser qualquer agente do Estado, precisamente servidor público ou agente que conte com a investidura de confiança por parte da Administração Pública. Registre-se, aliás, a recentíssima publicação da súmula 635 do STJ, que desejou pacificar a questão consignando o marco inicial da contagem do prazo 
prescricional a ciência da autoridade competente para a instauração, como já defendido pela CGU, embora pecando no aspecto técnico, como se verá adiante.

Desta forma, o presente artigo objetivou apresentar uma interpretação mais harmoniosa com o Estado de Direito do que a ofertada pela Corregedoria-Geral da União (CGU) e pelo STJ na súmula 635, especificamente em relação à contagem do prazo prescricional no âmbito disciplinar, incluindo os aspectos relacionados à aplicação da prescrição penal, de modo que se favoreça a segurança jurídica, a previsibilidade e a estabilidade das relações jurídicas e que seja compatível com o império da lei em um Estado Democrático de Direito.

Dada a necessidade de exercitar a interpretação de dispositivos legais, utilizou-se o método hermenêutico. A pesquisa, que é pura, abordou o problema qualitativamente de forma descritiva, utilizando os procedimentos técnicos bibliográfico e documental.

\section{O FENÔMENO DA PRESCRIÇÃO NO PROCESSO DISCIPLINAR}

Segundo relatório da Controladoria-Geral da União (CGU), desde o ano de 2003, em dados atualizados até abril de 2018, 5.744 (cinco mil setecentos e quarenta e quatro) servidores estatutários do Executivo Federal foram demitidos. Se forem considerados os casos de cassação de aposentadoria e destituição de cargo e de comissão, igualmente penas capitais, esse número chega a um total de 6.897 (seis mil oitocentos e noventa e sete) servidores. Considerando-se os primeiros quatro meses de 2018, 149 (cento e quarenta e nove) servidores foram demitidos, e somando-se aos que tiveram sua aposentadoria cassada ou foram destituídos de seus cargos ou funções, esse total chega a 183 (cento e oitenta e três). ${ }^{3}$

O comando legal determina que sempre que a Administração Pública tiver ciência da prática de irregularidade por parte do servidor, estará obrigada à imediata apuração, conforme artigo 143 da Lei 8.112/90: “A autoridade que tiver ciência de irregularidade no serviço público é obrigada a promover a sua apuração imediata, mediante sindicância ou processo administrativo disciplinar, assegurada ao acusado ampla defesa” (BRASIL, 1990).

Referido dispositivo estabelece uma ação vinculada e outra discricionária. A primeira é o dever de promover a apuração. A segunda, de caráter discricionário, mas igualmente

\footnotetext{
${ }^{3}$ Fonte: http://www.cgu.gov.br/assuntos/atividade-disciplinar/relatorios-de-punicoes-expulsivas/arquivos/ punicoes-abril-2018-estatutarios.pdf
} 
resultante de fundamentação e preenchimento de requisitos técnicos, é a escolha entre a instauração de um Processo Administrativo Disciplinar (PAD) ou um processo sindicante.

Ocorre que nem sempre essa apuração se dá de forma tão imediata. E, ainda, mesmo tendo sido instaurado algum processo disciplinar para apuração da suposta irregularidade em curto espaço de tempo, diversas circunstâncias podem retardar uma definição quanto à responsabilização do servidor e mesmo em relação ao julgamento da anunciada irregularidade.

Não seria razoável que o servidor estivesse sujeito a responder ad aeternum por suas ações no exercício de suas atribuições no cargo que ocupe. Para impedir essa situação de insegurança jurídica e instabilidade nas relações de trabalho, tem-se a existência do fenômeno da prescrição, assim chamado pela Lei n. 8.112/90, que estabelece o Regime Jurídico dos Servidores Públicos Civis da União, das Autarquias, inclusive as em regime especial, e das Fundações Públicas Federais.

A lei precitada estabelece os prazos, situações de interrupção e consequências do reconhecimento da prescrição. Trata-se de tema de singular relevância e que pode resultar na abstenção da aplicação de penalidade ao servidor acusado quando do julgamento pela autoridade competente.

É inquestionável o fato de que um processo disciplinar deva se desenvolver sob as luzes do Estado Democrático de Direito. Ocorre que o Estado de Direito tem assumido, hodiernamente, ao que nos parece, multifaces interpretativas, em não raras vezes incompatíveis entre si. Analisando os aspectos relacionados à prescrição, por exemplo, é possível constatar uma aparente indeterminação do Direito.

A segurança, previsibilidade e estabilidade das relações jurídicas são valores inerentes ao Estado Democrático de Direito. Essa segurança jurídica é uma espécie de mecanismo de proteção. A proteção se dá tanto em relação aos demais indivíduos quanto em relação ao próprio Estado. Não por outra razão as regras do jogo devem ser previamente conhecidas, sendo exigível um mínimo de previsibilidade.

O servidor público ${ }^{4}$, ao assumir um cargo público ${ }^{5}$ assume também uma série de deveres ${ }^{6}$ e se compromete a abster-se de um conjunto de proibições ${ }^{7}$ para o bom e adequado

\footnotetext{
${ }^{4}$ Lei 8.112/90, art. $2^{\text {o: }}$ [...] servidor é a pessoa legalmente investida em cargo público

${ }^{5}$ Lei 8.112/90, art. $3^{\circ}$ : Cargo público é o conjunto de atribuições e responsabilidades previstas na estrutura organizacional que devem ser cometidas a um servidor.
} 
desempenho de seu mister. Toda vez, porém, que o agente público descumpre o compromisso inicialmente assumido, nasce o poder-dever de a Administração Pública instaurar um processo disciplinar $^{8}$, com o fim de apurar a ocorrência de autoria e/ou materialidade ${ }^{9}$ e, se for o caso, aplicar uma sanção ${ }^{10}$ para as situações de indisciplina.

Chama-se responsabilidade administrativa o dever de o servidor responder por seus atos praticados no exercício de atividade administrativa estatal (JUSTEN FILHO, 2008, p. 804), podendo ser esta entendida também como aquela "que resulta do descumprimento de normas internas da entidade a que está vinculado, da violação do correto desempenho do cargo ou da infração de regras estatutárias" (GASPARINI, 2008, p. 244). Helly Lopes Meirelles (2012, p. 555) ensina que a responsabilidade administrativa resulta da violação de normas, de modo que a falta funcional gera o ilícito administrativo, que por sua vez dá ensejo à aplicação de uma pena disciplinar, sempre com atenção ao devido processo legal.

Não seria razoável, todavia, que o poder de punir do Estado vigesse por tempo indeterminado. Tal situação tornaria permanente a insegurança e a instabilidade nas relações de trabalho. Aliás, tem-se que o direito disciplinar em seu caráter punitivo não se propõe à caracterização da aplicação de uma penalidade com um valor intrínseco, algo que tenha um valor em si mesmo, mas, para o fim de alcance de legitimidade, deve buscar o aperfeiçoamento institucional e a pacificação e melhoria nas relações de trabalho. Quando, portanto, a Autoridade Administrativa se depara com a ocorrência do fenômeno da prescrição em um caso concreto, deve reconhecê-la e, em regra, determinar o arquivamento do processo.

Acerca da prescrição, Nestor Duarte (2008, p. 140) registra que "O vocábulo prescrição é originário de praescriptio, que deriva do verbo praescribere, significando 'escrever antes',", e deve ser compreendida como "a perda da exigibilidade do direito pelo decurso do tempo", não sendo a extinção do direito em si, mas a extinção de sua exigibilidade.

\footnotetext{
${ }^{6}$ Lei 8.112/90, art. 116 elenca os deveres dos servidores públicos, de modo exemplificativo, posto que consta como dever, por exemplo, observar as demais normas legais e regulamentares (inciso III).

${ }^{7}$ Lei 8.112/90, art. 117 elenca as proibições dos servidores públicos, de modo exemplificativo, vez que as demais proibições legais e regulamentares devem ser igualmente observadas.

${ }^{8}$ Lei 8.1128/90: Art. 143. A autoridade que tiver ciência de irregularidade no serviço público é obrigada a promover a sua apuração imediata, mediante sindicância ou processo administrativo disciplinar, assegurada ao acusado ampla defesa.

${ }^{9} \mathrm{Em}$ regra, quando se tem elementos suficientes de autoria e materialidade aponta-se para a pronta instauração de um procedimento administrativo disciplinar (PAD), e quando ausente a autoria e/ou a materialidade recomendável a instauração de processo sindicante.

${ }^{10}$ Lei 8.112/90, art. 127, elenca as penalidades disciplinares.
} 
O artigo 37, § 5º da Constituição da República Federativa do Brasil de 1988 (CRFB/88), estatui que “A lei estabelecerá os prazos de prescrição para ilícitos praticados por qualquer agente, servidor ou não, que causem prejuízos ao erário, ressalvadas as respectivas ações de ressarcimento." (BRASIL, 1988). A primeira parte do dispositivo, a saber, a determinação de existência de lei que estabeleça prazos de prescrição para ilícitos praticados por agentes públicos, foi atendida, por exemplo, pelo art. 142 da lei n. 8.112/90 (BRASIL, 1990) ${ }^{11}$, que diz:

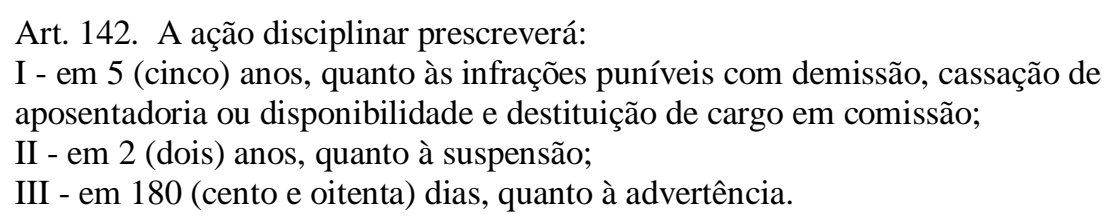

Prescrição, in casu, é o fenômeno pelo qual a Administração Pública, não instaurando o processo disciplinar contraditório adequado no tempo estabelecido ou, instaurando, não o concluindo no prazo proposto, perde o poder-dever de disciplinar o servidor público acusado, extinguindo-se a punibilidade, conforme determina o artigo 170 da Lei n. $8.112 / 90^{12}$. Celso Antônio bandeira de Mello (2009, p. 1038) sustenta que referido instituto foi concebido em favor da estabilidade e segurança jurídicas. Em manifestação similar, Sandro Lucio Dezan (2015, p. 526) afirma que o instituto da prescrição encontra fundamentos nos princípios da segurança jurídica e da certeza do direito.

A prescrição é matéria de ordem pública e não pode ser relevada pela Administração. Quer isso dizer que sempre que a autoridade administrativa estiver diante de uma situação de ocorrência de prescrição deve suscitá-la. Ou seja, em se tratando de processo disciplinar, a autoridade administrativa deve, ainda que não tenha sido alegada pela defesa, reconhecer a prescrição.

Há, registre-se, duas possibilidades e momentos de ocorrência da prescrição. A primeira, denominada no Manual de Processo Administrativo Disciplinar da CGU (2017, p. 315) de prescrição em perspectiva, ocorre nas situações em que, tendo tomado ciência do fato anunciado como ilícito, a autoridade competente tarda em instaurar um processo disciplinar regrado pelo contraditório.

\footnotetext{
${ }^{11}$ No Código Civil, o tratamento da matéria é dado pelo artigo 189: "violado o direito, nasce para o titular a pretensão, a qual se extingue, pela prescrição, nos prazos a que aludem os arts. 205 e 206.” (BRASIL, 2002)

${ }^{12}$ MS 23262/DF, rel. Min. Dias Toffoli, 23.4.2014. (MS-23262). Disponível em:

http://portal.stf.jus.br/processos/detalhe.asp?incidente=1734420. Acesso em: 11 abr. 2019.
} 
Importante ressaltar que apenas a instauração de sindicância contraditória/acusatória ou de PAD tem a capacidade de interromper a prescrição, nos termos do $\S 3^{\circ}$ do artigo 142 da Lei $8.112 / 90^{13}$. É nesse sentido o Enunciado n. 01, da CGU, publicado no DOU de 05/05/2011, Seção 01, pag. 22: “o processo administrativo disciplinar e a sindicância acusatória, ambos previstos pela lei n. ${ }^{\circ} 8.112 / 90$, são os únicos procedimentos aptos a interromper o prazo prescricional" (GCU, 2011).

Por ser matéria de ordem pública, a prescrição pode ser alegada a qualquer tempo. Conforme já salientado, a autoridade julgadora tem o dever de, verificando-a, anunciar sua ocorrência, podendo invocar o art. 52, da Lei n. 9.784/99: “O órgão competente poderá declarar extinto o processo quando exaurida sua finalidade ou o objeto da decisão se tornar impossível, inútil ou prejudicado por fato superveniente” (BRASIL, 1999). Nesse sentido, se a autoridade administrativa sabe antecipadamente que não se tornará possível a aplicação de penalidade em razão da ocorrência da prescrição, não parece eficiente e razoável o seguimento do processo.

O enunciado CGU n. 04, de 05 de maio de 2011, afirma que

A Administração Pública pode, motivadamente, deixar de deflagrar procedimento disciplinar, caso verifique a ocorrência de prescrição antes da sua instauração, devendo ponderar a utilidade e a importância de se decidir pela instauração em cada caso.

Indigitado enunciado faz referência à constatação da ocorrência de prescrição antes da instauração do processo disciplinar. Todavia, parece-nos ser o caso de aplicação da regra mesmo no caso de constatação de ocorrência de prescrição após a instauração, ou seja, durante os trabalhos da comissão. Aliás, é aconselhável que a comissão, ao se deparar com uma situação similar, durante os trabalhos, possa consultar à autoridade julgadora, ou mesmo a autoridade instauradora, para análise precisa quanto à ocorrência ou não da prescrição e da necessidade de continuidade do processo disciplinar, dada a ocorrência de fato superveniente capaz de retirar a possibilidade de fim útil ao processo.

\footnotetext{
${ }^{13}$ Nesse sentido, STJ. MS 11644/DF. Sandro Lucio Dezan (2015, p. 529) destaca que "apesar de pacífico em doutrina que a sindicância punitiva (contraditorial) e o processo administrativo disciplinar possuem a mesma natureza jurídica, qual seja, o processo em sentido estrito, e, por isso, a prescrição somente se interrompe, uma única vez, com a instauração de um desses procedimentos, a Terceira Seção do Superior Tribunal de Justiça, em decisão de 13.08.2014, MS 9677/DF, Mandado de Segurança 2004/0056744-0, atribuiu - a nosso sentir, de forma equivocada - possível natureza distinta entre os institutos (sindicância e PAD) para conceber mais de uma interrupção do prazo prescricional[...]".
} 
Trata-se da chamada prescrição intercorrente, que se dá no curso do processo. É a situação na qual, mesmo tendo a Autoridade competente instaurado o procedimento disciplinar adequado, os trabalhos da comissão ou a prolação do julgamento não se dá no prazo fixado em Lei. Não se está falando da eventual extrapolação do prazo para conclusão dos trabalhos por parte da comissão ${ }^{14}$ ou do prazo fixado em Lei para prolação do julgamento ${ }^{15}$, incapazes, a priori, de gerar nulidade absoluta. Aborda-se aqui o fato de após o decurso do prazo estabelecido em Lei para conclusão do processo ${ }^{16}$, e reiniciada a contagem do prazo prescricional, o processo alcance a duração de 180 (cento e oitenta) dias, 2 (dois) ou 5 (cinco) anos, a depender se a situação está sujeita a advertência, suspensão ou demissão, consumando-se, então, o termo da prescrição.

A disciplina legal "parece permitir que a interrupção se prolongue até o infinito, bastando, para tanto, que não seja proferida decisão no respectivo processo administrativo" (CARVALHO FILHO, 2014, p. 1011). É que a Lei fala em até a decisão final proferida por autoridade competente. Obviamente, essa decisão deve ser proferida dentro lapso temporal legalmente estabelecido, sob pena de reinício da contagem do prazo prescricional.

Desse modo, após a ciência do fato a Administração Pública tem 180 (cento e oitenta) dias, 2 (dois) ou 5 (cinco) anos, a depender da modalidade de punição prevista ${ }^{17}$, para instaurar o processo acusatório adequado, sob pena de consumação da prescrição. Há de ser considerada a pena em abstrato, ou seja, aquela penalidade estabelecida diretamente pela legislação, em que pese a possibilidade de justificativa para aplicação de penalidade mais grave, como no caso da reincidência de casos passíveis de advertência.

Instaurando a sindicância acusatória ou PAD, a contagem do prazo prescricional será interrompida e voltará a ser contada após 80 (oitenta), 50 (cinquenta) ou 140 (cento e

\footnotetext{
${ }^{14}$ Os prazos são de 30 dias, prorrogável por igual período, para a sindicância, nos termo do artigo 145, p. único; de 60 (sessenta) dias, prorrogável por igual período, para os casos de rito ordinário, nos termos do artigo 152; e 30 dias, prorrogável por até 15 dias, conforme artigo 133 , $\S 7^{\circ}$, todos da Lei 8.112/90.

${ }^{15} \mathrm{O}$ art. 167 da Lei 8.112/90 estabelece o prazo de 20 (vinte) dias contados do recebimento do processo para a autoridade julgadora proferir a sua decisão em relação ao PAD sob o rito ordinário, e o parágrafo $4^{\circ}$ do art. 133 , o prazo de 5 (cinco) dias para o PAD sob o rito sumário.

${ }^{16}$ Sindicância $(30+30+20=80)$, PAD Rito Sumário $(30+15+5=50)$ e PAD Rito Ordinário $(60+60+20=140)$, considerando-se os prazos para as comissões concluírem os trabalhos, o período de prorrogação, e o prazo para julgamento.

${ }^{17}$ Vide artigos 129 e 132 da Lei 8.112/90
} 
quarenta) dias da instauração, a depender se fora instaurado uma sindicância, um PAD sob o rito sumário ${ }^{18}$ ou um PAD sob o rito ordinário, respectivamente.

Importante destacar que o artigo 170 da Lei n. 8.112/90, que previa que "Extinta a punibilidade pela prescrição, a autoridade julgadora determinará o registro do fato nos assentamentos individuais do servidor", foi declarado inconstitucional pelo Supremo Tribunal Federal (STF) ${ }^{19}$, em sede de Mandado de Segurança, ou seja, com efeito, a priori, inter partes. Na tentativa de sacramentar a questão sobreveio parecer vinculante da AGU firmando entendimento no sentido de que "no âmbito dos processos administrativos disciplinares, uma vez extinta a punibilidade pela prescrição, a autoridade julgadora não poderá fazer o registro do fato nos assentamentos individuais do servidor público" (AGU, 2016).

Sendo a prescrição a perda da pretensão punitiva do Estado pelo decurso do tempo, necessário ainda esclarecer que para cada um dos tipos de penalidades administrativas a Lei 8.112/90 estabelece um determinado prazo prescricional. Importante, então, analisar os tipos de penalidades apresentados pelo referido diploma legal para consequente identificação do prazo prescricional e a adequada contagem desse prazo. Aliás, para a correta contagem do prazo prescricional é imprescindível, também, saber o tempo legal estabelecido para duração dos procedimentos disciplinares, conforme já explicitado anteriormente.

\section{AS PENALIDADES PREVISTAS NA LEI 8.112/90 E A CONTAGEM DO PRAZO PRESCRICIONAL}

Os servidores públicos estão sujeitos ao cometimento de irregularidades. Quando a Administração Pública, após um processo em que sejam garantidos o contraditório e ampla defesa, constata o cometimento de desvio de conduta expressamente tipificado, abusando da redundância, tem o dever de aplicar uma sanção, que é a consequência danosa que o legislador atribuiu a quem viola a lei. (COSTA, 2007, p. 221).

São três os tipos de penalidade apresentados pela Lei $8.112 / 90^{20}$ : i) advertência; ii) suspensão; e iii) as penas expulsivas, a saber, demissão, cassação de aposentadoria ou

\footnotetext{
${ }^{18}$ O rito sumário é disciplinado no art. 133 da Lei 8.112/90 e é aplicável nos casos de acumulação ilegal de cargos, inassiduidade habitual e abandono de cargo, nos termo do art. 140 do mesmo diploma legal.

${ }^{19}$ MS 23262/DF, rel. Min. Dias Toffoli, 23.4.2014. (MS-23262). Disponível em: http://portal.stf.jus.br/processos/detalhe.asp?incidente=1734420. Acesso em: 11 abr. 2019.

${ }^{20} \mathrm{O}$ art. 127 da lei 8.112/90 assenta que o servidor público está passível de sofrer as seguintes penalidades: I advertência, II - suspensão, III - demissão, IV - cassação de aposentadoria ou disponibilidade, V - destituição de cargo em comissão e VI - destituição de função comissionada.
} 
disponibilidade e ainda a destituição de cargo em comissão. Para cada uma destas três situações a Lei estabelece um prazo determinado como lapso temporal para ocorrência da prescrição.

Importa, antes, dizer uma obviedade: na seara do direito disciplinar não há que se falar em penalidades que resultem em condenações pecuniárias ou privações compulsórias de sua remuneração ou de seus bens, posto que o ingresso na vida patrimonial do indivíduo se dá, em regra, sob as diretrizes do Direito Civil; e igualmente não há que se falar em privação de liberdade, medidas alternativas compulsórias etc., uma vez que tais medidas dizem respeito ao Direito Penal.

No Direito Administrativo, notadamente o disciplinar, as consequências pela prática de ilícitos administrativos são, como anteriormente afirmado, a advertência, a suspensão e aquelas expulsivas, nos termo do artigo 127 da Lei n. 8.112/90, destacando-se, todavia, a possibilidade de aplicação de sanções cumulativamente nas searas civis, penais e administrativas, conforme artigo 125 do mesmo dispositivo legal.

No caso da advertência, a Lei estabeleceu que "a ação disciplinar prescreverá" em 180 (cento e oitenta) dias. Para as situações de suspensão o prazo prescricional é de 2 (dois) anos. E para as situações de penalidades expulsivas esse prazo é de 5 (cinco) anos. Esses prazos prescricionais são fixados no artigo 142 da Lei n. 8.112/90.

Nos termos artigo 142, $\S 1^{\circ}$, "o prazo de prescrição começa a correr da data em que o fato se tornou conhecido". Mas conhecido por quem? Por qualquer um do povo? Por qualquer um da Administração Pública? Por qualquer servidor público? Por qualquer servidor Público da Instituição envolvida? Ou conhecido pela Autoridade competente para instaurar o processo disciplinar?

Veja-se que, aparentemente, não há que se falar em início de contagem do prazo prescrição em relação a ilícito efetivamente praticado mas que não tenha sido do conhecimento por parte da Administração, uma vez que o prazo tem sua contagem a partir do seu conhecimento.

A lei 8.112/90 foi completamente silente em estabelecer, afinal, a partir da ciência de quem o prazo prescricional teria sua contagem iniciada. Dado esse vácuo, o Órgão Central do Sistema de Correição do Poder Executivo Federal tem manifestado entendimento no sentido de que esse prazo tem início apenas após a ciência da autoridade competente para a 
instauração do processo disciplinar, embora a Lei nada tenha dito em relação a isso (CGU, 2017).

A favor daqueles que entendem que apenas a ciência do ilícito pela autoridade competente para instaurar o respectivo procedimento disciplinar é suficiente para deflagrar o início da contagem do prazo prescricional está a preocupação de que o entendimento em sentido diverso concorra para uma menor eficácia do poder disciplinar. Ainda, não faria sentido a fixação de uma espécie de "sanção" à inércia da autoridade administrativa, posto que outro comportamento não poderia ser validamente esperado, vez que sequer tinha conhecimento da ocorrência do ilícito.

O STJ sumulou entendimento acerca dessa situação nos seguintes moldes, por ocasião da novíssima súmula 635 :

\footnotetext{
Os prazos prescricionais previstos no artigo 142 da Lei 8.112/1990 iniciam-se na data em que a autoridade competente para a abertura do procedimento administrativo toma conhecimento do fato, interrompem-se com o primeiro ato de instauração válido - sindicância de caráter punitivo ou processo disciplinar - e voltam a fluir por inteiro, após decorridos 140 dias desde a interrupção.
}

Equivocou-se, todavia, o STJ ao estabelecer que o prazo prescricional deve voltar a correr após 140 (cento e quarenta) dias. Em verdade voltará nesse período se estivermos tratando da instauração de um PAD sob o rito ordinário. Diferentemente será se for o caso de instauração de PAD rito sumário ou de sindicância acusatória, cujos prazos serão, respectivamente, de 50 (cinquenta) e 80 (oitenta) dias.

Esse entendimento, ademais, é capaz de produzir uma situação na qual uma irregularidade praticada há décadas pudesse chegar ao conhecimento da autoridade competente apenas nos dias atuais e então pudesse ser suficiente para a deflagração de um procedimento disciplinar, em desarmonia à segurança jurídica e estabilização das relações sociais, especialmente no ambiente de trabalho, frustrando, inclusive, a priori, o aspecto pedagógico inserido no agir disciplinar.

A segunda linha de entendimento, a saber, aquela que fixa a compreensão no sentido de que o prazo prescricional deve ser iniciado a partir do momento em que qualquer agente do Estado, precisamente servidor público ou agente que conte com a investidura de confiança por parte da Administração Pública, toma ciência da conduta tida como ilícita parece ser a mais adequada.

Observemos que consta como dever do servidor, conforme inciso VI do artigo 116 da Lei 8.112/90, "levar as irregularidades de que tiver ciência em razão do cargo ao 
conhecimento da autoridade superior ou, quando houver suspeita de envolvimento desta, ao conhecimento de outra autoridade competente para apuração" (BRASIL, 1990). A consequência para aquele que deliberadamente, por indulgência, deixa de responsabilizar subordinado que tenha cometido alguma infração no exercício do cargo ou, não possuindo competência para tal, não leva o fato ao conhecimento da autoridade competente, é a invocação do direito penal, vez que comete, em tese, condescendência criminosa, tipificada no art. 320 do Código Penal (CP).

Portanto, tendo sido consumada a prescrição por ação ou omissão deliberada de agente público, representante do Estado, não é o servidor acusado quem deva ser penalizado, mas, sim, aquele que deu causa. Nesse sentido, parece-nos acertado o entendimento que extrai do artigo $142, \S 1^{\circ}$, da Lei n. 8.112/90, a compreensão que aponta o início da contagem do prazo prescricional para o conhecimento por parte de servidor público ou agente público que conte com a investidura de confiança por parte da Administração Pública, e não somente conhecimento por parte da autoridade competente para a apuração ou instauração do processo disciplinar.

A advertência é a mais branda das penalidades a ser aplicada a um servidor público e será invocada nos casos de violação ao artigo 117, incisos I a VII e XIX, da Lei 8.112/90, ou nos casos de inobservância de dever funcional, regulamento, norma interna, que não justifique imposição de penalidade mais grave, conforme orientação indicada no artigo 129 do mesmo diploma legal. A subsunção aos incisos do artigo 116 (Deveres) da Lei 8.112/90 igualmente guarda vinculação à penalidade de advertência.

A penalidade de advertência consiste no registro escrito no assento funcional do servidor. Por essa penalidade a Administração comunica ao servidor que ele cometeu ilícito administrativo de natureza leve, e com essa comunicação há uma incitação a que não volte a atuar de modo reprovável, sob pena de padecer sanções mais severas. Marçal Justen Filho (2008, p. 814) defende que "pode haver efeitos acessórios da advertência, tal como a redução da avaliação positiva para fins de promoção por merecimento".

A suspensão será aplicada nos casos de reincidência das faltas punidas com advertência ou quando da violação das demais proibições que não tipifiquem infração sujeita à penalidade de demissão, tendo como limite o prazo de 90 (noventa) dias, e "pode ser definida como o afastamento temporário compulsório, imposto ao servidor público como punição por ato reprovável funcional” (JUSTEN FILHO, 2008, p. 814). Não se deve 
confundir com aplicação da penalidade de suspensão a medida cautelar referente ao afastamento preventivo do servidor acusado, medida esta prevista no artigo 147 da Lei n. 8.112/90, que embora não seja penalidade, deve ser tratada como medida última e extrema e de aplicação excepcional, devidamente fundamentada.

Na suspensão há um efeito ou consequência patrimonial, especialmente em relação à remuneração ou subsídio do servidor. Marçal Justen Filho (2008, p. 815) ensina que "O silêncio da Lei n. 8.112/90 e a previsão de que suspensão comporta conversão em multa na base de $50 \%$ por dia de vencimento (ficando o servidor obrigado a permanecer em serviço) conduzem à conclusão de que a suspensão não elimina o direito à remuneração". Contudo, o renomado doutrinador parece ter incorrido em raro equívoco. A suspensão ocasiona a perda da remuneração ou subsídio correspondente; ou do contrário não seria penalidade, mas espécie de "férias" remuneradas e verdadeiro prêmio pela conduta ilícita. A possibilidade de conversão em multa na base de $50 \%$ por dia de vencimento ou remuneração quer dizer que o servidor sofrendo a suspensão nada receberia, e trabalhando, no lugar de receber $100 \%$ do valor devido receberá apenas a metade (50\%).

Avançando, o artigo 132 da Lei n. 8.112/90 trata da demissão, embora queira estabelecer as situações passíveis de aplicação das penalidades expulsivas, que implicam na extinção do vínculo entre o servidor e a Administração.

Ao analisar a prescrição no Executivo Federal é possível notar que a previsibilidade desejável em questões de direito é mitigada, especialmente em relação à interpretação dada pela CGU e agora mais recentemente pelo STJ em entendimento sumulado. Mas, seguimos firmes no sentir de que o mais adequado e alinhado ao Estado de Direito seria uma interpretação no sentido de que o fato ao ser conhecido pela Administração, independentemente se por meio de autoridade com competência ou não para instaurar processo disciplinar, ensejaria o início da contagem do prazo prescricional.

Em um Estado Democrático de Direito, em que vige o império da lei, há de se fazer um alerta às interpretações e ações que pretendem dizer o que a Lei seguramente não disse, com implicação em prejuízo aos indivíduos, especialmente em processos sancionadores. Essa discussão tem um forte impacto na relação entre os direito administrativo e penal.

\section{PRESCRIÇÃO ADMINISTRATIVA DISCIPLINAR E DIREITO PENAL}


O tipo penal cria para o Estado o direito de punir em abstrato. A partir da escolha dos bens jurídicos a serem penalmente tutelados, a legislação sinaliza à sociedade a obrigação de abstração de determinados comportamentos sob a ameaça de imposição de uma pena. Essa diretriz de comportamento, que é ainda abstrata, passa a ganhar forma com a violação da norma penal incriminadora. Deste modo, o que era um direito do Estado de exigir a abstenção da prática criminosa, passa a ser um dever de impor ao desviante a pena prevista no preceito secundário da norma.

Assim nasce o jus puniendi estatal, representado pelo poder-dever de punir o sujeito transgressor da norma penal. Após o trânsito em julgado da sentença condenatória, este direito de punir concreto converte-se em jus executionis, significando o dever de executar a sanção imposta pelo Juiz na sentença. Em ambos os momentos de manifestação do Estado não pode o acusado/condenado aguardar ad aeternum pelo provimento estatal para aplicar-lhe a consequência da imputação feita. ${ }^{21}$

São diversas as razões que podem levar à necessidade de reconhecimento da prescrição no ordenamento jurídico penal. Cezar Roberto Bitencourt (2013, p. 1026) chama a atenção para as seguintes: i) o decurso do tempo leva ao esquecimento do fato; ii) o decurso do tempo leva à recuperação do criminoso; iii) o Estado deve arcar com a sua inércia e; iv) o decurso do tempo enfraquece o suporte probatório. ${ }^{22}$

De todo modo, cometido um crime ${ }^{23}$, inicia-se um duelo entre o poder punitivo estatal e o direito de liberdade do transgressor. Este primeiro conflito é deflagrado pela prática do ilícito penal e perdura até o trânsito em julgado da sentença penal condenatória. Tem-se, assim, conforme ressaltado alhures, a configuração do jus puniendi, o qual, somente com o trânsito em julgado da sentença condenatória, dá lugar ao jus executionis, ressalvado o recente entendimento do STF que flexibilizou o assunto. A compreensão dos limites de cada manifestação do poder punitivo estatal é fundamental para a compreensão da prescrição em

\footnotetext{
${ }^{21}$ Uma justificativa para esta constatação pode ser encontrada em autores da escola clássica do direito penal, tais como Cesare Beccaria e Jeremy Bentham. Beccaria (2000, p. 26), no seminal tratado Dos Delitos e das Penas, por exemplo, defendendo a necessidade de as penas acompanharem os delitos, a fim de servirem de prevenção geral, desestimulando os demais sujeitos da prática de atos igualmente criminosos, defende seja estipulado um prazo para o exercício do poder punitivo estatal, uma vez que "a obscuridade que envolveu por muito tempo o delito diminui muito a necessidade do exemplo."

${ }^{22}$ No mesmo sentido, Damásio E. de Jesus (2008, p. 19).

${ }^{23}$ Embora o Código Penal adote a teoria da ação para a definição do tempo do crime (artigo $4^{\circ}$ ), especialmente em relação à prescrição o Código adota a teoria do resultado. Mais ainda, com relação aos crimes tentados ou permanentes, adota a teoria da atividade.
} 
matéria penal, dado que a primeira manifestação resulta na prescrição da pretensão punitiva, enquanto a segunda na prescrição da pretensão executória ${ }^{24}$.

A primeira importância da delimitação está nas consequências do reconhecimento da prescrição em cada momento processual: se até o trânsito em julgado da sentença penal condenatória, o reconhecimento da prescrição (da pretensão punitiva) resulta na eliminação de todos os efeitos do crime. ${ }^{25}$ Equivale à abstração de considerar que ele nunca foi cometido. ${ }^{26}$ Na prescrição da pretensão executória, a extinção da punibilidade impede somente a execução da pena. Sendo assim, é possível que haja punição administrativa mesmo quando reconhecida a prescrição da pretensão executória no Juízo penal.

Nesta modalidade de prescrição há uma sensível diferença em relação ao tratamento da matéria pelo Direito Administrativo: o termo inicial da contagem da prescrição, conforme artigo 111 do CP, é a data da consumação do fato ou a data em que cessou a atividade criminosa, diferentemente do que preceitua o $\$ 1^{\circ}$ do artigo 142 da Lei 8.112/90. ${ }^{27}$ Desta forma, é possível que um mesmo fato que tenha repercutido tanto na esfera penal quanto administrativa seja alcançado pela prescrição naquela e não nesta instância. ${ }^{28}$

Esta prescrição - da pretensão punitiva - pode ainda ser abstrata, retroativa ${ }^{29}$ ou intercorrente $^{30}$. Destacando-se o que é relevante para o problema desta pesquisa, a prescrição

\footnotetext{
${ }^{24}$ Esta modalidade de prescrição utiliza a pena aplicada na sentença condenatória. Diferentemente dos efeitos do reconhecimento da prescrição da pretensão punitiva, o reconhecimento desta forma de prescrição não tem o poder de desfazer os efeitos penais e extrapenais da condenação, exceto a própria execução da pena.

${ }^{25}$ Damásio E. de Jesus (2008, p. 26) destaca como efeitos a extinção da punibilidade e, consequentemente, por analogia do art. 748 do Código de Processo Penal, a vedação ao registro dos antecedentes criminais.

${ }^{26}$ Nesse sentido, Cezar Roberto Bitencourt (2013, p. 1027).

${ }^{27} \mathrm{O}$ dispositivo estabelece que o prazo de prescrição começa a contar da data em que o fato se tornou conhecido.

28 Ilustrativamente, pode-se considerar um caso em que o servidor público recebeu valores indevidos de particulares em razão do cargo que ocupa. Tal fato repercute tanto na esfera administrativa (Art. 132, XI, da Lei 8.112/90) quanto na penal (Art. 317 do CP). Pela regra do $\$ 2^{\circ}$ do artigo 142 da Lei 8.112/90, a prescrição será regulada pelo prazo do artigo 109 do $\mathrm{CP}$ (neste exemplo, 16 anos). Ocorre que a prescrição penal considera o início da contagem do prazo na consumação do fato ou cessação da atividade criminosa, enquanto a administrativa, a data em que o fato se tornou conhecido. Assim, se o crime tiver sido consumado no dia 10 de abril de 2003, mas a Administração somente tenha tomado conhecimento dele, v. g., com a deflagração do processo penal, em 10 de abril de 2005, a prescrição penal alcançará o crime no dia 09 de abril de 2019 , e a administrativa somente no dia 09 de abril de 2021.

${ }^{29}$ Esta modalidade de prescrição leva em consideração a pena in concreto aplicada na sentença, desde que não haja recurso pela acusação ou, havendo, tenha sido desprovido. A ideia é que, fixada a pena na sentença, deve ser esse o quantum suficiente para a contagem da prescrição, o que, por ser até este momento desconhecido, deu lugar à pena abstratamente prevista para o tipo. Tecnicamente, este prazo deveria ser considerado, inclusive, para constatação da prescrição entre a consumação do fato e o oferecimento da denúncia. Contudo, como manifestação de uma equivocada maneira de se combater a impunidade, em vez de aparelhar as polícias e Ministério Público, optou-se por afastar a possibilidade de reconhecimento da prescrição retroativa para o período entre a prática do crime e o oferecimento da denúncia (art. $110, \S 1^{\circ}$, do $\mathrm{CP}$, acrescentado pela Lei $12.234 / 10)$.
} 
da pretensão punitiva abstrata considera a pena como prevista no preceito secundário do tipo penal (por isso abstrata). Neste ponto surge uma reflexão: no tratamento da matéria pela Lei 8.112/90, o legislador, talvez no afã de alargar os prazos prescricionais nos casos que sejam também definidos como crime pela legislação penal, limitou-se a referenciar apenas os prazos prescricionais dos crimes. Assim, em uma primeira leitura, diante de um PAD instaurado em decorrência da prática de peculato (inciso I do art. 132 da Lei 8.112/90), a autoridade administrativa deveria olhar para a pena prevista no $\mathrm{CP}$ para a mesma conduta e, a partir da ciência do fato, proceder à contagem da prescrição observando os critérios do artigo 109 do $\mathrm{CP}$.

Ocorre que a técnica para a identificação do prazo prescricional do artigo 109 do CP deve levar em conta, ainda, as majorantes ou minorantes obrigatórias (considerando nestas o fator que menos diminua e naquelas o que mais aumente, dada a priorização do interesse público) e a redução do prazo à metade motivada pela idade do agente no momento da prática do ato (se menor de 21 anos) ou no momento da sentença (se maior de 70 anos).

Desta forma, embora o $\S 2^{\circ}$ do artigo 142 da Lei 8.112/90 faça referência apenas aos prazos prescricionais da lei penal, o que pode levar a uma leitura isolada dos artigos 109 e 110 do CP, defende-se deva ser considerado no cálculo prescricional para efeito na esfera administrativo as causas de redução definidas no artigo 115 do CP (idade do agente) por ser fundamental à matéria. Ademais, sendo o Direito Penal a ultima ratio, não é razoável seja o reconhecimento da prescrição mais rigoroso no âmbito administrativo do que no penal.

\section{CONCLUSÃO}

Vigora no Direito Brasileiro a independência entre as instâncias civil, administrativa e penal, inclusive no que se refere à prescrição. Apresentou-se a prescrição como fenômeno pelo qual a Administração Pública, não instaurando o processo disciplinar no tempo e modo adequados ou, instaurando, não o concluindo no prazo estabelecido, perde o poder-dever de disciplinar o servidor público acusado do cometimento de irregularidade administrativa, extinguindo-se a punibilidade, conforme determina o artigo 170 da lei n. 8.112/90.

No caso do Executivo Federal, esfera analisada no presente trabalho, a lei estabeleceu os prazos de 180 (cento e oitenta) dias, 2 (dois) e 5 (cinco) anos para prescrição

\footnotetext{
${ }^{30}$ A prescrição da pretensão punitiva intercorrente (ou superveniente) também leva em conta a pena in concreto. Difere-se, contudo, da retroativa, por voltar-se para o momento posterior à sentença condenatória recorrível. Deste modo, verifica-se esta modalidade de prescrição no período compreendido entre a sentença condenatória recorrível e o trânsito em julgado da sentença.
} 
da ação disciplinar, respectivamente, nas situações de advertência, suspensão e as penalidades expulsivas. Esse prazo diz respeito à pena administrativa em abstrato. Desse modo, a leitura dos artigos 129, 130 e 132 da lei n. 8.112/90 nos apresenta de imediato qual o prazo prescricional deve ser observado.

Assim, ainda que haja entendimento especialmente da CGU no sentido da possibilidade de majoração de uma penalidade de advertência para suspensão pela mera existência de "justificativa" apresentada pela Administração, invocando-se a parte final do art. 129 da Lei n. 8.112/90, o prazo prescricional cravado deve ser aquele fixado em abstrato, ou seja, no caso dado, o prazo de 180 (cento e oitenta) dias. Do contrário, ficaria ao arbítrio da Administração encontrar sempre que desejasse uma majorante ou justificativa para aplicação de penalidade maior, e a partir dessa equivocada interpretação, jamais se submeteria ao prazo prescricional a penalidade mais branda prevista na legislação.

Restaram consignadas as duas possibilidade de ocorrência da prescrição: prescrição em perspectiva e a prescrição intercorrente. A primeira tendo sua ocorrência antes da instauração do processo disciplinar, e a segunda com a consumação do prazo fatal após a instauração, mas antes do julgamento e aplicação da penalidade.

Não seria razoável que o servidor estivesse sujeito a ser responsabilizado indefinidamente no tempo por suas ações. E é justamente para impedir essa situação de insegurança jurídica e instabilidade nas relações de trabalho que o instrumento da prescrição deve ser observado, sendo, aliás, matéria de ordem pública, passível de constatação a qualquer tempo.

Advém do Estado de Direito valores como a segurança jurídica, a previsibilidade, especialmente das ações coercitivas do Estado, e a estabilidade das relações jurídicas. Em atenção aos valores e à própria ideia de Estado de Direito, de império da lei, é que se defendeu a inadequação da interpretação, defendida pela CGU e sumulada pelo STJ na súmula 635 , de que a contagem do prazo prescricional tem início apenas com a ciência da autoridade competente para instaurar o processo disciplinar.

Contrariamente a esse posicionamento, defendeu-se que a contagem do prazo prescricional deve ter início tão logo o fato seja do conhecimento da Administração Pública, por qualquer de seus agentes, sendo eventual inércia passível de apuração também na seara disciplinar, e até criminal, mas jamais podendo impactar na previsibilidade estabelecida em lei. 
Embora tenha havido uma tentativa de aproximação das matérias administrativa e penal por parte do $\S 2^{\circ}$ do artigo 142 da Lei 8.112/90, o fato é que os seus regramentos são próprios. Destaca-se como exemplo desta diferenciação o marco inicial da contagem do prazo prescricional: enquanto a precisão penal inicia-se com a consumação do fato ou cessação da atividade criminosa, no âmbito administrativo, sobretudo pela disciplina dada pela Lei 8.112/90, o marco inicial para a contagem do prazo prescricional é a data em que o fato se tornou conhecido. Sendo desta forma, é possível imaginar situações em que um mesmo fato dê ensejo à instauração de processo penal e administrativo, mas a prescrição alcance apenas um deles.

Sobre a referência feita pelo $\S 2^{\circ}$ do artigo 142 da Lei 8.112/90 no sentido de que os prazos prescricionais previstos na lei penal aplicam-se às medidas disciplinares também definidas como crime, propôs-se devam ser consideradas as majorantes e minorantes obrigatórias e a redução do prazo à metade motivada pela idade do agente, nos termos do artigo 115 do Código Penal. A sugestão parte da subsidiariedade do direito penal. Não sendo desta forma, corre-se o risco de ver o direito administrativo punir com maior rigor do que o processo criminal, e certamente essa não era a intenção do legislador, tampouco a medida que nos pareça mais razoável e próxima à interpretação conforme a Constituição.

Não se descuida da máxima de que o direito administrativo e o direito penal tutelam bens jurídicos eventualmente distintos. Contudo, o que não parece razoável é que a última ferramenta de que dispõe o Estado seja menos gravosa do que as demais disponíveis. Exatamente por isso, embora o $\S 2^{\circ}$ do artigo 142 da Lei 8.112/90 faça referência apenas aos prazos prescricionais da lei penal, a leitura sistemática do dispositivo deve permitir a compreensão de que as majorantes e minorantes obrigatórias, bem como as causas de redução do prazo prescricional (art. 115 do CP), devem ser consideradas na importação de tais prazos feita pelo art. $142, \S 2^{\circ}$, Lei $8.112 / 90$.

\section{BIBLIOGRAFIA}

BECCARIA, Cesare. Dos delitos e das penas. 2. ed. Trad. Torrieri Guimarães. São Paulo: Martin Claret, 2000. 
BITENCOURT, Cezar Roberto. Tratado de direito penal: parte geral. 19. ed. rev. ampl. e atual. São Paulo: Saraiva, 2013.

BRASIL. Constituição (1988). Constituição da República Federativa do Brasil, de 5 de outubro de 1988. Brasília, DF, 5 out. 1988. Disponível em:

http://www.planalto.gov.br/ccivil_03/Constituicao/Constituicao.htm. Acesso em: 2 abr. 2019.

BRASIL, Lei $\mathrm{n}^{\circ}$ 8.112, de 11 de novembro de 1990. Dispõe sobre o regime jurídico dos servidores públicos civis da União, das autarquias e das fundações públicas federais. Brasília, DF, 11 nov. 1990. Disponível em: http://www.planalto.gov.br/ccivil_03/LEIS/L8112cons.htm. Acesso em: 2 abr. 2019.

BRASIL, Lei $n^{\circ}$ 9.784. Regula o processo administrativo no âmbito da Administração Pública Federal. Brasília, DF, 29 jan. 1999. Disponível em: http://www.planalto.gov.br/ccivil_03/leis/19784.htm. Acesso em: 2 abr. 2019.

BRASIL. Lei no 10.406. Código Civil. Brasília, DF, 10 de janeiro de 2002. Disponível em: http://www.planalto.gov.br/ccivil_03/LEIS/2002/L10406.htm. Acesso em: 2 abr. 2019.

BRASIL. Superior Tribunal de Justiça. Súmula n. 635. Os prazos prescricionais previstos no artigo 142 da Lei 8.112/1990 iniciam-se na data em que a autoridade competente para a abertura do procedimento administrativo toma conhecimento do fato, interrompem-se com o primeiro ato de instauração válido - sindicância de caráter punitivo ou processo disciplinar e voltam a fluir por inteiro, após decorridos 140 dias desde a interrupção. Brasília, DF:

Superior Tribunal de Justiça, [2019]. Disponível em:

http://www.stj.jus.br/docs_internet/VerbetesSTJ.pdf. Acesso em: 14 jul 2019.

CARVAlHO FILHO, José dos Santos. Manual de Direito Administrativo. 27. ed. rev. ampl. e atual. São Paulo: Atlas, 2014.

CORREGEDORIA-GERAL DA UNIÃO. Manual de processo administrativo disciplinar. Brasília, DF, 2017. Disponível em: https://www.cgu.gov.br/Publicacoes/atividadedisciplinar/arquivos/manual-pad-versao-janeiro-2017.pdf/view. Acesso em: 2 abr. 2019.

CORREGEDORIA-GERAL DA UNIÃO, Enunciado 01. Disponível em: https://www.cgu.gov.br/assuntos/atividade-disciplinar/comissao-de-coordenacao-decorreicao/enunciados-e-demais-documentos-aprovados. Acesso em: 2 abr. 2019.

COSTA, Nelson Nery. Processo administrativo e suas espécies. Rio de Janeiro: Forense, 2007. 
DEZAN, Sandro Lucio. Fundamentos de direito administrativo disciplinar. 3. ed. rev. e atual. Curitiba: Jurua, 2015.

DUARTE, Nestor in PELUZO, Cezar (Coord.). Código civil comentado: doutrina e jurisprudência. 2. ed. ver. e atual. São Paulo: Manole, 2008.

GASPARINI, Diogenes. Direito administrativo. 13. ed. rev. e atual. São Paulo: Saraiva: 2008.

JESUS, Damásio E. de. Prescrição penal. 17. ed. São Paulo: Saraiva, 2008.

JUSTEN FILHO, Marçal. Curso de direito administrativo. 3. ed. rev. e atual. São Paulo: Saraiva, 2008.

MELLO, Celso Antônio Bandeira de. Curso de Direito Administrativo. 26. ed. ver. e atual. São Paulo: Malheiros, 2009.

MEIRELLES, Helly Lopes; ALEIXO; Délcio Balestero; BURLE FILHO, José Emmanuel. Direito administrativo brasileiro. 38. ed. São Paulo: Malheiros, 2012. 